This document was prepared in conjunction with work accomplished under Contract No. DE-AC09-96SR18500 with the U.S. Department of Energy.

This work was prepared under an agreement with and funded by the U.S. Government. Neither the U. S. Government or its employees, nor any of its contractors, subcontractors or their employees, makes any express or implied: 1 . warranty or assumes any legal liability for the accuracy, completeness, or for the use or results of such use of any information, product, or process disclosed; or 2 . representation that such use or results of such use would not infringe privately owned rights; or 3 . endorsement or recommendation of any specifically identified commercial product, process, or service. Any views and opinions of authors expressed in this work do not necessarily state or reflect those of the United States Government, or its contractors, or subcontractors. 


\title{
Modified Borohydrides for Reversible Hydrogen Storage (2)
}

\author{
Ming $\mathrm{Au}^{*}$ \\ Savannah River National Laboratory, Aiken, SC29808, USA
}

\begin{abstract}
This paper reports the results in the effort to destabilize lithium borohydride for reversible hydrogen storage. A number of metals, metal hydrides, metal chlorides and complex hydrides were selected and evaluated as the destabilization agents for reducing dehydriding temperature and generating dehydriding-rehydriding reversibility. It is found that some additives are effective. The Raman spectroscopic analysis shows the change of $\mathrm{B}-\mathrm{H}$ binding nature.
\end{abstract}

Key Word: Lithium Borohydride, Hydrogen, Storage, Reversibility

\section{Introduction}

The highest gravimetric $(18.4 \mathrm{wt} \%)$ and volumetric $\left(121 \mathrm{~kg} / \mathrm{m}^{3}\right)$ hydrogen content of lithium borohydrides motivate great deal of research activities to make this material as effective hydrogen storage media. The main focus of lithium borohydride research is to reduce dehydrogenation temperature and to make material reversible - rechargeable at the moderate condition. In our previous work, several oxides have been found effective reduce the dehydrogenation temperature of $\mathrm{LiBH}_{4}$ from $673 \mathrm{~K}$ to $473 \mathrm{~K}$. These modified $\mathrm{LiBH}_{4}$ based materials show $8 \sim 9 \mathrm{wt} \%$ reversible hydrogen storage capacity at $873 \mathrm{~K}$ and $7 \mathrm{MPa}$ [1]. Although this is an encouraging step forward, the elevated recharging conditions are still impractical for on-board hydrogen storage application. Further more, the most hydrogen $(5-7 \mathrm{wt} \%)$ has been librated at above $573 \mathrm{~K}$. It is believed that the oxides may play the role as the decomposition promoters (or catalysts) for releasing hydrogen at lower temperature. The fundamental change of thermodynamic stability of $\mathrm{LiBH}_{4}$ is demanded for reversible hydrogen storage at the moderate conditions.

It is reported that the electrons in ionic compounds such as $\mathrm{LiBH}_{4}$ and $\mathrm{NaBH}_{4}$ are strongly localized, i.e. highly ionic, which gives these materials their stable thermodynamics [2,3]. Partial substitution of the cation (the $\mathrm{Li}^{+1}$ in $\mathrm{LiBH}_{4}$ ) with other cations may change the borohydride bond structure, hopefully producing weakened B-H bond strengths, since such substitution of metal cations with less metallic cations should reduce the ionic character of the $\mathrm{M}^{+1}$ (metal)-[BH4 $]^{-1}$ system and delocalize its electrons resulting in lower stability. In other words, the thermodynamic stability of the metal borohydrides $\mathrm{M}^{\mathrm{a}} \mathrm{BH}_{4}$ can be reduced by partial substitution of the metal element $\mathrm{M}^{\mathrm{a}}$ with the element $\mathrm{M}^{\mathrm{b}}$ where $\mathrm{M}^{\mathrm{b}}$ is less metallic in nature than $\mathrm{M}^{\mathrm{a}}$. By carefully selecting $\mathrm{M}^{\mathrm{b}}$, 
the B-H bonds could be weakened and the enthalpy $(\Delta \mathrm{H})$ of decomposition of the metal borohydride can be reduced, resulting in a lower dehydrogenation temperature.

This concept is expressed by follow dehydrogenation equations:

$$
\begin{array}{cc}
M^{a} B H_{4} \Leftrightarrow M H+B+\frac{3}{2} H_{2} & \Delta \mathrm{H}_{\mathrm{a}} \\
M_{1-x}^{a} M_{x}^{b} B H_{4} \Leftrightarrow M_{1-x}^{a} M_{x}^{b} H+B+\frac{3}{2} H_{2} & \Delta \mathrm{H}_{\mathrm{ab}} \\
\Delta \mathrm{H}_{\mathrm{ab}}<\Delta \mathrm{H}_{\mathrm{a}} &
\end{array}
$$

In this work, the research has been focused on weakening the B-H bond in an attempt to further lower dehydriding temperature and ease rehydrogenation conditions while holding high hydrogen storage capacity. The particularly designed formulations and the processes have been developed to exercise the new concept [4]. The experiment data have been presented in this paper.

\section{Technical Approach}

Several metals, metal hydrides and metal chlorides were added to $\mathrm{LiBH}_{4}$ as the potential destabilization agents. A mechano-thermal diffusion process (MTDP) has been developed to execute the element partial substitution in order to reduce thermodynamic stability of $\mathrm{LiBH}_{4}$. The new materials were then examined for their hydrogen desorption and absorption properties in an attempt to find less stable, reversible, high capacity storage materials.

\section{Experimental Details}

The $\mathrm{LiBH}_{4}$ powder (99.99\% purity) and the destabilization agents (metals, metal hydrides and metal chlorides 99.9-99.99\% purity) were purchased from Sigma-Aldrich and used directly without any pre-treatment. Two grams of the appropriate $\mathrm{LiBH}_{4}+$ agents powder mixture was placed in a $25 \mathrm{ml}$ hardened steel grinding bowl with three $11 \mathrm{~mm}$ diameter tungsten carbide balls in the argon glove box. The sealed grinding bowls were taken out of the glove box and put on Frisch-7 planetary ball mill for 2 hours of $600 \mathrm{rpm}$ milling to mix the powder homogeneously. To promote elements diffusion and substitution, the powder mixtures were transferred to a stainless steel reactor for sintering at $350^{\circ} \mathrm{C}$ and $100 \mathrm{MPa}$ for 8 hours. To reduce the particle size and improve kinetics, the sintered materials were crushed and ball milled with the catalyst $\mathrm{TiCl}_{3}$ for 10 hours at $600 \mathrm{rpm}$. The process was named as Mechano-thermal diffusion process (MTDP). Then, new materials were ready for evaluation of hydrogen storage performance. All materials transferring were conducted in the argon glove box.

A semi-automatic Sieverts apparatus was used for Temperature-Programmed-Desorption (TPD) measurements at $5^{\circ} \mathrm{C} / \mathrm{min}$, isothermal hydrogen desorption and absorption. Selected destabilized borohydrides were investigated by Raman spectroscopy (Raman) to determine their binding structure change. 


\section{Results and Discussion}

\section{$\underline{4.1} \underline{\text { TPD Screening of the Modified } \mathrm{LiBH}_{4}} \underline{\text { Based Materials }}$}

In this investigation, sixteen modified $\mathrm{LiBH}_{4}$ based materials have been synthesized (Table 1) and evaluated using TPD. Eight of them show the positive effect of the additives such as $\mathrm{Mg}, \mathrm{Al}, \mathrm{MgCl}_{3}, \mathrm{MgH}_{2}, \mathrm{CaH}_{2}, \mathrm{TiCl}_{3}$ and $\mathrm{LiAlH}_{4}$ on destabilization of materials. But, other additives such as $\mathrm{NaH}, \mathrm{Ni}, \mathrm{Ca}$, In and graphite exhibit the negative influence on reduction of dehydrogenation temperature. Some agents show mix effect on destabilization. The detail results are discussed as below.

Table1. The modified LiBH4 materials

\begin{tabular}{|l|l|l|l|}
\hline \multirow{2}{*}{ Sample } & \multicolumn{1}{|c|}{ Composition } & \multicolumn{2}{|c|}{ Preliminary result } \\
\cline { 3 - 4 } & & Positive & Negative \\
\hline 1 & $\mathrm{LiBH}_{4}+0.2 \mathrm{Mg}$ & $\mathrm{x}$ & \\
\hline 2 & $\mathrm{LiBH}_{4}+0.2 \mathrm{MgCl}_{2}+0.1 \mathrm{TiCl}_{3}$ & $\mathrm{x}$ & \\
\hline 3 & $\mathrm{LiBH}_{4}+0.5 \mathrm{LiAlH}_{4}$ & $\mathrm{x}$ & \\
\hline 4 & $\mathrm{LiBH}_{4}+0.076 \mathrm{MgCl}_{2}+0.047 \mathrm{TiCl}_{3}$ & $\mathrm{x}$ & \\
\hline 5 & $\mathrm{LiBH}_{4}+0.5 \mathrm{MgH}_{2}+2 \% \mathrm{TiCl}_{3}$ & $\mathrm{x}$ & \\
\hline 6 & $\mathrm{LiBH}_{4}+0.5 \mathrm{AlH}$ & & \\
\hline 7 & $\mathrm{LiBH}_{4}+0.5 \mathrm{NaH}$ & $\mathrm{x}$ & $\mathrm{x}$ \\
\hline 8 & $\mathrm{LiBH}_{4}+0.5 \mathrm{NaH}+0.1 \mathrm{TiO}_{2}$ & & $\mathrm{x}$ \\
\hline 9 & $\mathrm{LiBH}_{4}+0.2 \mathrm{C}$ & & $\mathrm{x}$ \\
\hline 10 & $\mathrm{LiBH}_{4}+0.2 \mathrm{C}+0.01 \mathrm{TiCl}$ & & $\mathrm{x}$ \\
\hline 11 & $\mathrm{LiBH}_{4}+0.04 \mathrm{Ni}$ & & $\mathrm{x}$ \\
\hline 12 & $\mathrm{LiBH}_{4}+0.2 \mathrm{Al}$ & $\mathrm{x}$ & \\
\hline 13 & $0.95 \mathrm{LiBH}_{4}+0.05 \mathrm{Ca}$ & & $\mathrm{x}$ \\
\hline 14 & $0.95 \mathrm{LiBH}_{4}+0.05 \mathrm{In}$ & & $\mathrm{x}$ \\
\hline 15 & $\mathrm{LiBH}_{4}+0.1 \mathrm{Al}+0.05 \mathrm{TiO}_{2}$ & & $\mathrm{x}$ \\
\hline 16 & $\mathrm{LiBH}_{4}+0.5 \mathrm{CaH}$ & & \\
\hline
\end{tabular}

\subsubsection{Metal-Modified $\mathrm{LiBH}_{4}$ Based Materials}

Commercial $\mathrm{LiBH}_{4}$ decomposes starting at approximately $573 \mathrm{~K}$ at a slow rate. At about $450{ }^{\circ} \mathrm{C}$, the decomposition rate appreciably accelerates, resulting in a final release of 9 $\mathrm{wt} \%$ hydrogen at $873 \mathrm{~K}$. In this investigation, $\mathrm{LiBH}_{4}$ was modified by ball milling with metals $\mathrm{Mg}, \mathrm{Al}, \mathrm{Ca}$, In and graphite carbon. The TPD results (Fig.1) show that $\mathrm{Mg}$ and $\mathrm{Al}$ having positive influence on stability reduction, but $\mathrm{Ca}$, In, $\mathrm{Ni}$ and carbon graphite are negative additives. Material $\mathrm{LiBH}_{4}+0.2 \mathrm{Mg}$ librated $1 \mathrm{wt} \%$ of hydrogen starting from 330 $\mathrm{K}$ at a very slow rate. The dehydriding accelerated when temperature increased above $573 \mathrm{~K}$ and desorbed $9 \mathrm{wt} \%$ of hydrogen upon to $873 \mathrm{~K}$. As an additive, aluminum also shows a positive effect on reducing dehydrogenation temperature. The material $\mathrm{LiBH}_{4}+0.2 \mathrm{Al}$ librated $0.2 \mathrm{wt} \%$ of hydrogen at $340 \mathrm{~K}$ slowly and $7.8 \mathrm{wt} \%$ of hydrogen from $573 \mathrm{~K}$ to $873 \mathrm{~K}$ rapidly. It is interested that there are two plateaus at $673 \mathrm{~K}$ and 773 $\mathrm{K}$ respectively in the TPD curve of this aluminum doped $\mathrm{LiBH}_{4}$. It is the indications of 
the formations of the intermediate compounds, the products of $\mathrm{LiBH}_{4}$ and $\mathrm{Al}$ interaction. These compounds may less or more stable than $\mathrm{LiBH}_{4}$. It is our hope to find the less stable intermediate compounds with low desorption temperature and reversibility.

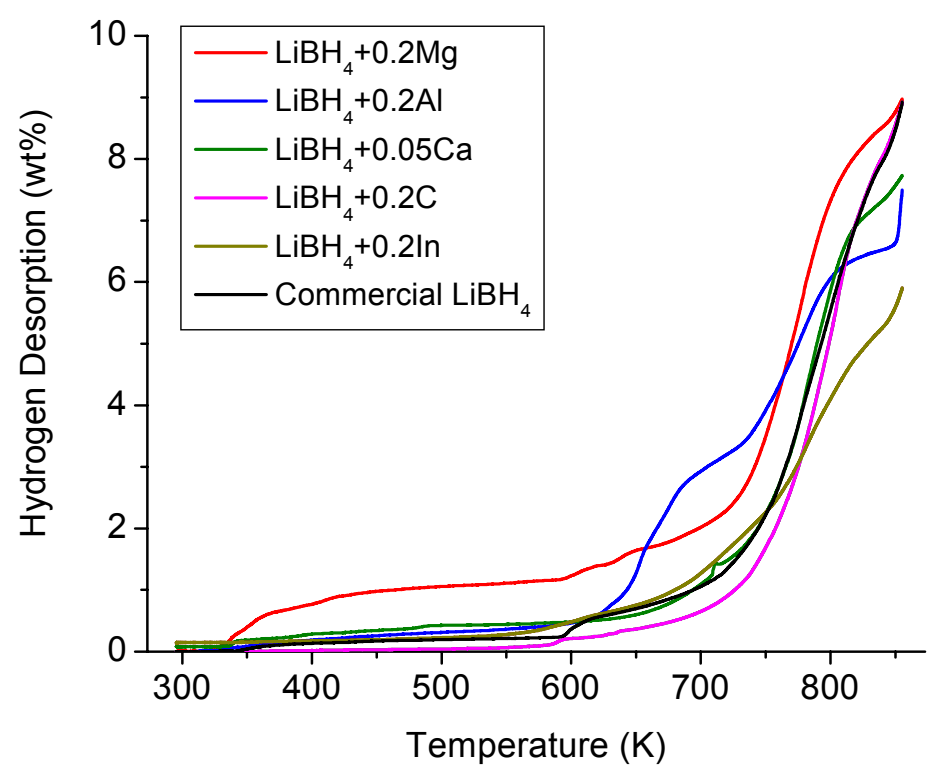

Fig.1 TPD of metal doped $\mathrm{LiBH}_{4}$ based materials

To investigate the benefit of $\mathrm{Al}$ doping, the material $\mathrm{LiBH}_{4}+0.24 \mathrm{Al}$ was rehydrided at 10 $\mathrm{MPa}$ and $873 \mathrm{~K}$ after first desorption at $873 \mathrm{~K}$ and $500 \mathrm{~Pa}$. Then the second desorption was carried out. As Fig. 2 shows, the first plateau disappears in the second TPD, desorption starting temperature gone up from $340 \mathrm{~K}$ to $623 \mathrm{~K}$ and capacity decreased from $8 \mathrm{wt} \%$ to $3.5 \mathrm{wt} \%$. It appears that the Al-doping produced more stable and irreversible material. 


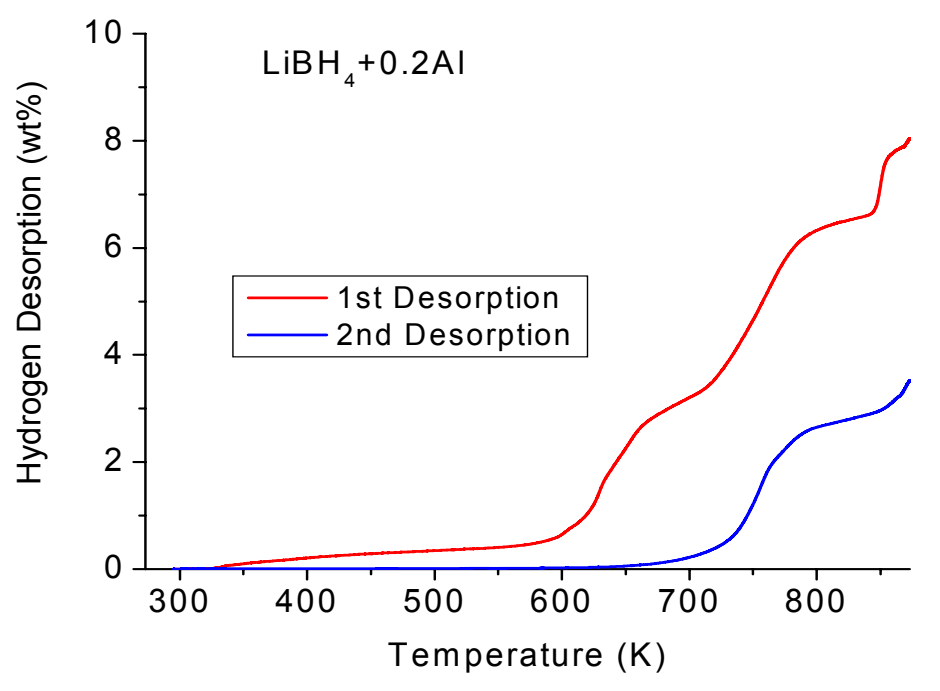

Fig.2 Rapidly dehydriding of $\mathrm{LiBH}_{4}+0.2 \mathrm{Al}$

The additives, $\mathrm{Ca}$, In and graphite carbon show no or negative influence on reduction of hydrogen desorption temperature. They also did not generate the plateau in TPD curves. It appears that the lithium borohydride has no interaction with the metals $\mathrm{Ca}$, In and carbon.

\subsubsection{Metal Chloride-Modified $\mathrm{LiBH}_{4}$ Based Materials}

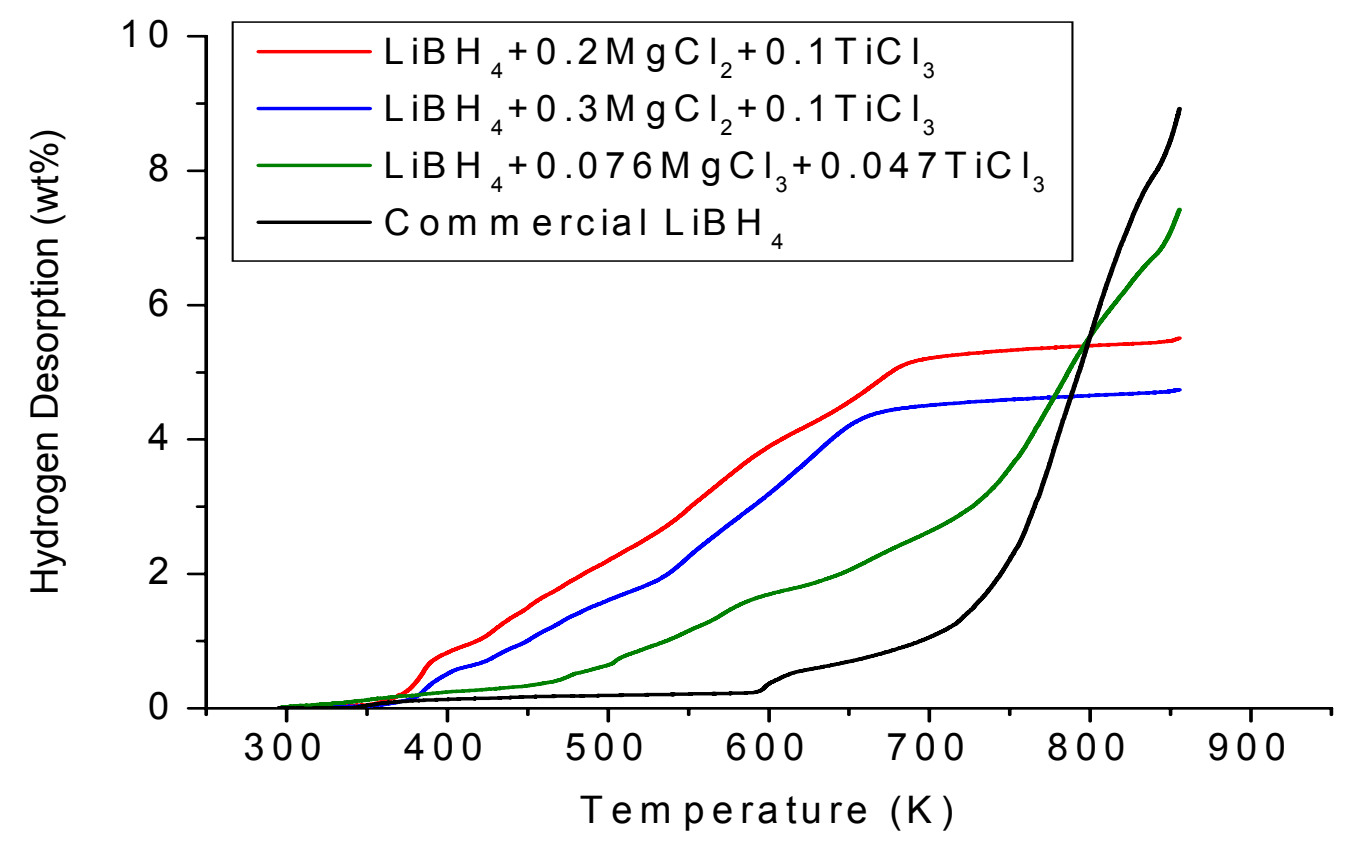

Fig.3 TPD of $\mathrm{LiBH}_{4}$ based materials modified by $\mathrm{MgCl}_{2}$ and $\mathrm{TiCl}_{3}$ 
In this investigation, three $\mathrm{LiBH}_{4}$ based materials modified by $\mathrm{MgCl}_{2}$ and $\mathrm{TiCl}_{3}$ at different molar ratios have been synthesized using MTDP process. Their TPD results are shown in Fig.3. Material $\mathrm{LiBH}_{4}+0.2 \mathrm{MgCl}_{2}+0.1 \mathrm{TiCl}_{3}$ released $5.5 \mathrm{wt} \%$ hydrogen starting from $330 \mathrm{~K}$. Unlike metal oxide-modified $\mathrm{LiBH}_{4}$ that have the typical slow dehydrogenation rate below $623 \mathrm{~K}[1]$, the material $\mathrm{LiBH}_{4}+0.2 \mathrm{MgCl}_{2}+0.1 \mathrm{TiCl}_{3}$ desorbed $5.2 \mathrm{wt} \%$ hydrogen linearly at high rate from $330 \mathrm{~K}$ to $673 \mathrm{~K}$. The additives $\left(\mathrm{MgCl}_{2}\right.$ and $\mathrm{TiCl}_{3}$ ) also changed the TPD curve shapes by comparing with oxide modified $\mathrm{LiBH}_{4}$ and commercial $\mathrm{LiBH}_{4}$. This may imply that some less stable intermediate compounds with less thermodynamic stability form during processes. Identifying and generating more this kind of intermediate compounds might result in more hydrogen being released at lower temperature. As material $\mathrm{LiBH}_{4}+0.3 \mathrm{MgCl}_{3}+0.2 \mathrm{TiCl}_{3}$ shows, increasing additives loading did little in reducing dehydrogenation temperature further, but decreased hydrogen storage capacity about $0.9 \mathrm{wt} \%$. As material $\mathrm{LiBH}_{4}+0.076 \mathrm{Cl}_{3}+0.047 \mathrm{TiCl}_{3}$ shows in Fig.3, decreasing additive loading resulted in capacity increase, lower dehydrogenation temperature, slow reaction and shape change of the curve.

It is encouraging that the most reaction of dehydrogenation was completed below $673 \mathrm{~K}$ although the capacity is low. It is believed that the additives $\mathrm{MgCl}_{3}$ and $\mathrm{TiCl}_{3}$ may reduce the thermodynamic stability of $\mathrm{LiBH}_{4}$ through interaction or possible formation of intermediate compounds. The comprehensive material characterization will provide the clues. The overall low capacity of $\mathrm{MgCl}_{2}$ and $\mathrm{TiCl}_{3}$ doped $\mathrm{LiBH}_{4}$ is attributed to heavy additive loading $(67.4 \mathrm{wt} \%)$. Obviously, the optimization of the additive loading will increase the dehydriding capacity while retain lower dehydriding temperature. The material $\mathrm{LiBH}_{4}+0.3 \mathrm{MgCl}_{3}+0.2 \mathrm{TiCl}_{3}$ was selected for evaluation of the isothermal desorption and absorption. The results will be discussed later.

\subsubsection{Metal Hydride-Modified $\mathrm{LiBH}_{4}$ Based Materials}

In an attempt to form less-stable intermediate compound, several metal hydrides such as $\mathrm{MgH}_{2}, \mathrm{AlH}_{3}, \mathrm{LiAlH}_{4}$ were added into $\mathrm{LiBH}_{4}$ using MTDP process.

The material $\mathrm{LiBH}_{4}+0.5 \mathrm{MgH}_{2}+2 \% \mathrm{TiCl}_{3}$ desorbed $8.5 \mathrm{wt} \%$ hydrogen at $873 \mathrm{~K}$. There are two stages in desorption curve. The first desorption released about $2.8 \mathrm{wt} \%$ hydrogen slowly from $373 \mathrm{~K}$ to $673 \mathrm{~K}$ and the second one librated $5.8 \mathrm{wt} \%$ from $673 \mathrm{~K}$ to $873 \mathrm{~K}$ with relatively fast desorption rate. The first stage may attribute to $\mathrm{MgH}_{2}$ dehydriding and the second one may correspond to $\mathrm{LiBH}_{4}$ dehydriding. The possible interaction of $\mathrm{LiBH}_{4}$ and $\mathrm{MgH}_{2}$ may take place during ball milling and following dehydriding at certain temperature. The result agrees with Vajo's claim. He believes that the intermediate compound $\mathrm{MgB}_{2}$ plays a role in making reaction reversible [5].

The material $\mathrm{LiBH}_{4}+0.5 \mathrm{AlH}_{3}$ desorbed $8.5 \mathrm{wt} \%$ hydrogen in two steps. It released hydrogen slowly from $373 \mathrm{~K}$. Above $453 \mathrm{~K}$, the dehydrogenation rate picks up and the material delivered $2.5 \mathrm{wt} \%$ hydrogen at $493 \mathrm{~K}$. This step may be dominated by decomposition of $\mathrm{AlH}_{3}$. There is no significant hydrogen desorption between $493 \mathrm{~K}$ and $673 \mathrm{~K}$. Above $673 \mathrm{~K}$, the material desorbed about $5.8 \mathrm{wt} \%$ hydrogen until $873 \mathrm{~K}$. The 
second step attributes mainly to decomposition of $\mathrm{LiBH}_{4}$. It is unlikely that the $\mathrm{Al}$ element substitutes some of the B as expected.

The material $\mathrm{LiBH}_{4}+0.5 \mathrm{LiAlH}_{4}$ desorbed hydrogen starting from $453 \mathrm{~K}$ in two stages. The material desorbed about $3 \mathrm{wt} \%$ hydrogen in the low temperature stage (below $553 \mathrm{~K}$ ) and $6.2 \mathrm{wt} \%$ in high temperature stage (above $673 \mathrm{~K}$ ). It is known that $\mathrm{LiAlH}_{4}$ decomposes at $448 \mathrm{~K}$ and liberates about $7.5 \mathrm{wt} \%$ hydrogen. The two stages of dehydrogenation may reflect the some mixed behavior of $\mathrm{LiAlH}_{4}$ and $\mathrm{LiBH}_{4}$. But, most hydrogen comes from $\mathrm{LiBH}_{4}$ based on the molar ratio. The possible interaction of $\mathrm{LiAlH}_{4}$ and $\mathrm{LiBH}_{4}$ is warranted for investigation to produce less stable materials.

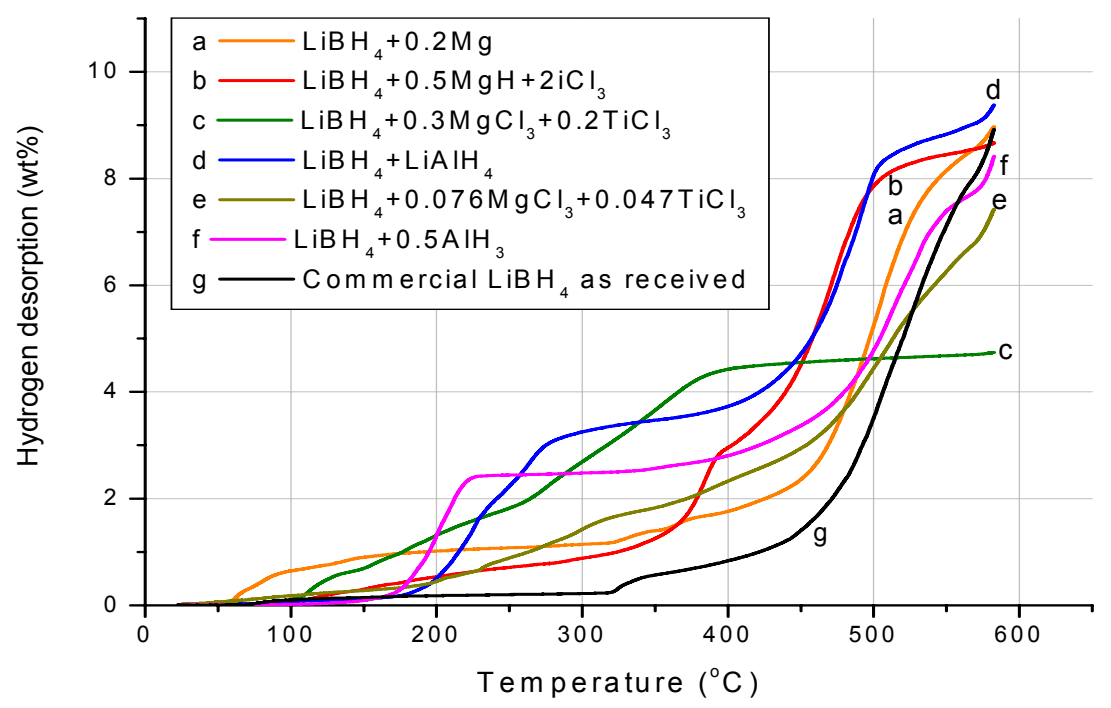

Fig.3. Hydrogen desorption of the modified $\mathrm{LiBH}_{4}$ materials with positive effect

Although the positive influence of the additives on dehydrogenation of $\mathrm{LiBH}_{4}$ is discussed in above, it is realized that some additives have negative effect on dehydrogenation of $\mathrm{LiBH}_{4}$ as Fig. 2 shows. We don't have sufficient material characterization data to interpreter the negative effect yet. One possible reason is that the $\mathrm{Na}$ substitutes Li to form more stable $\mathrm{NaBH}_{4}$ in the $\mathrm{LiBH}_{4}+0.5 \mathrm{NaH}$ and $\mathrm{LiBH}_{4}+0.5$ $\mathrm{NaH}+0.1 \mathrm{TiO}_{2}$. The sample $11\left(\mathrm{LiBH}_{4}+0.04 \mathrm{Ni}\right)$ and $14\left(\mathrm{LiBH}_{4}+0.05 \mathrm{In}\right)$ also show negative results, but not is listed in the chart. 


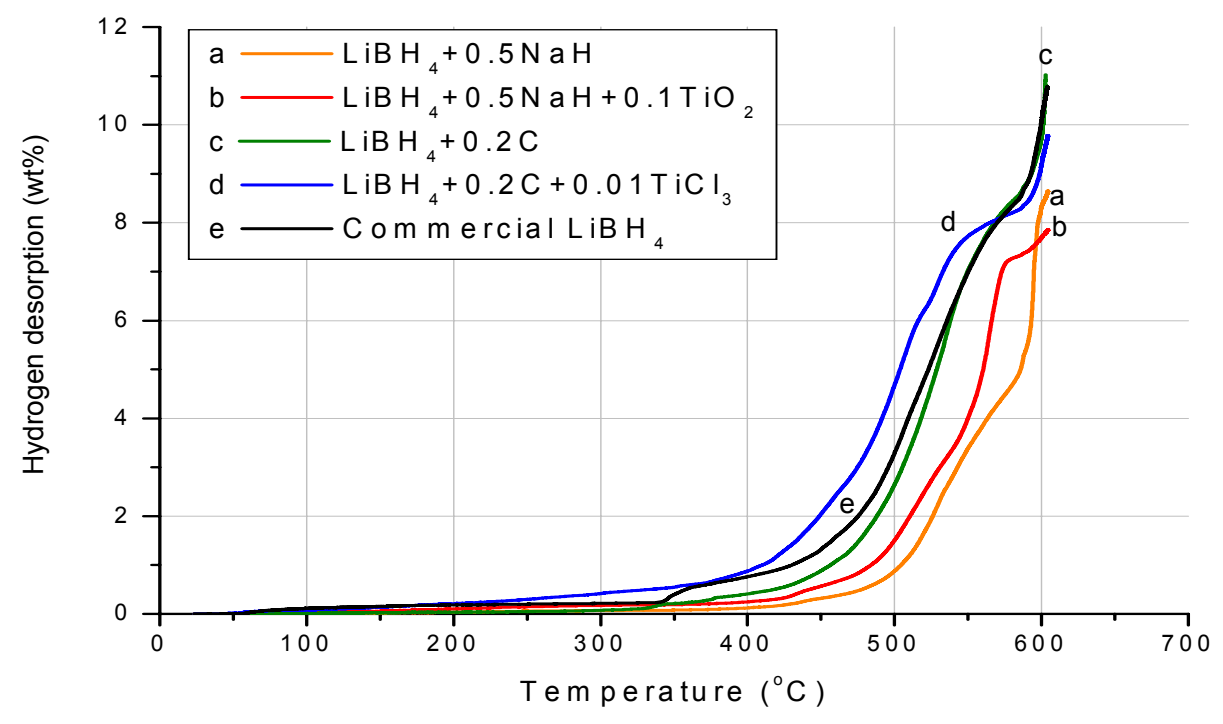

Fig.4. Hydrogen desorption of the modified $\mathrm{LiBH}_{4}$ materials with negative effect

Several other metals and metal hydrides such as $\mathrm{Al}, \mathrm{Ca}$ and $\mathrm{CaH}_{2}$ were also added into $\mathrm{LiBH}_{4}$ as the destabilization agents. The results are given in Fig.5. It is found that the Al and $\mathrm{CaH}_{2}$ reduced the decomposition temperature to less than $323 \mathrm{~K}$ in the samples $11\left(81.7 \mathrm{wt} \% \mathrm{LiBH}_{4}+18.3 \mathrm{wt} \% \mathrm{Al}\right)$ and $15\left(75 \mathrm{wt} \% \mathrm{LiBH}_{4}+10 \mathrm{wt} \% \mathrm{Al}+15 \mathrm{wt} \% \mathrm{TiO}_{2}\right)$. The sample 11 desorbed $3 \mathrm{wt} \%$ of hydrogen at $673 \mathrm{~K}$ and $8 \mathrm{wt} \%$ of hydrogen at $873 \mathrm{~K}$.

However, it desorbed $3.5 \mathrm{wt} \%$ of hydrogen at $873 \mathrm{~K}$ only in the second dehydriding after rehydriding at $873 \mathrm{~K}$ and $10 \mathrm{MPa}$, see Fig. 6 . It is doubt if the material is reversible, the more work is needed.

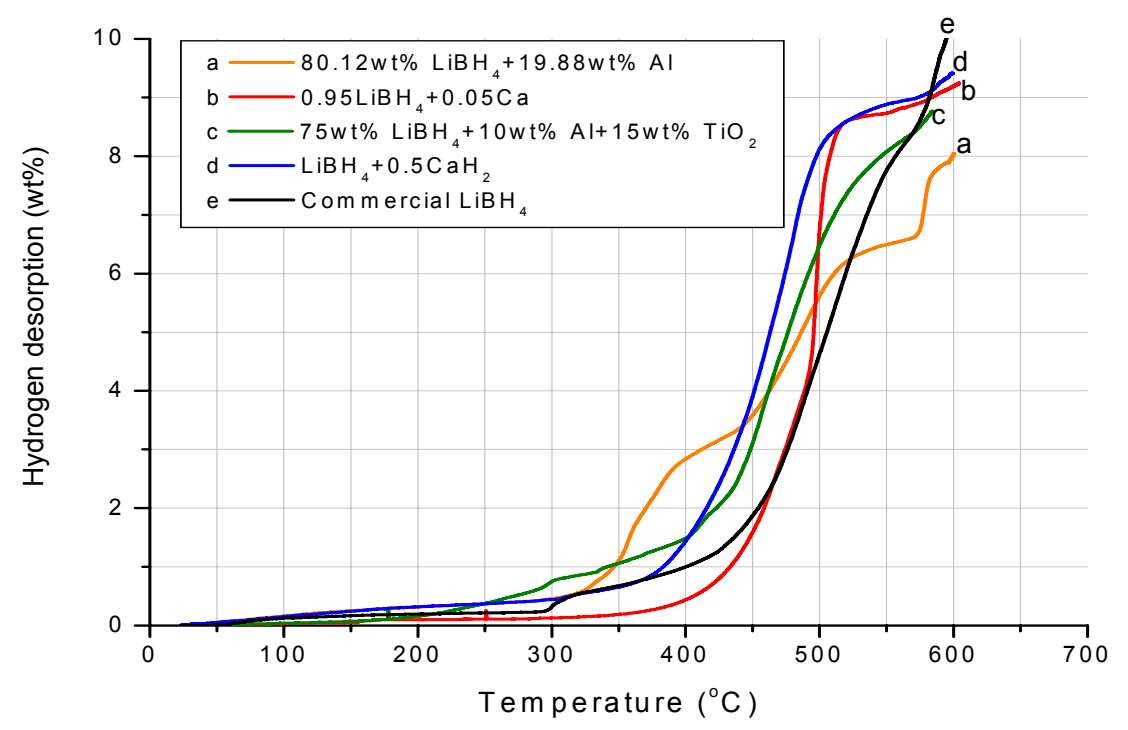

Fig.5 Hydrogen desorption of the modified $\mathrm{LiBH}_{4}$ materials with mix effect 
The material $0.95 \mathrm{LiBH}_{4}+0.05 \mathrm{Ca}$ shows the negative effect of adding $\mathrm{Ca}$ metal. But, the material $\mathrm{LiBH}_{4}+0.5 \mathrm{CaH}_{2}$ shows the positive role of $\mathrm{CaH}_{2}$ in the reducing of the decomposition temperature. It is believed that the $\mathrm{Ca}$ metal is covered by the $\mathrm{CaO}$ layer preventing $\mathrm{Ca}$ from interaction with $\mathrm{LiBH}_{4}$. Differently, $\mathrm{CaH}_{2}$ can provide the fresh metallic Ca during thermal decomposition and ball milling.

In summary, the additives $\mathrm{Mg}, \mathrm{MgCl}_{3}$ and $\mathrm{TiCl}_{3}$ reduced dehydriding temperature from $593 \mathrm{~K}$ to $373 \mathrm{~K}$ or less (samples 1, 2 and 4). The dehydrogenations were completed in a single stage. The positive effect of these additives implies that the thermodynamic stability of the $\mathrm{LiBH}_{4}$ was reduced due to possible partial substitution of $\mathrm{Li}$ by $\mathrm{Mg}$, but more supporting evidences have to be generated such as $\mathrm{P}-\mathrm{T}-\mathrm{C}$ isotherms and advanced spectrum analysis. The additives $\mathrm{LiAlH}_{4}, \mathrm{AlH}_{3}$ and $\mathrm{MgH}_{2}$ also reduced dehydriding temperature and produced more hydrogen at lower temperature (samples 3, 5 and 6). The dehydrogenations were completed in two stages, low temperature and high temperature. Somehow, the two stages may be dominated by the decomposition of the hydrides additives and the $\mathrm{LiBH}_{4}$ in the lower and higher temperature ranges respectively. But, the interaction of additives with $\mathrm{LiBH}_{4}$ have to be considered. MTD process may promote the interaction and produce the interesting intermediate compounds that play the important role as the bridge to facilitate the reversible reaction at moderate condition. $\underline{4.2}$ Isothermal dehydrogenation of the selected modified borohydrides

Although the TPD show a whole picture of the dehydrogenation process in a broad temperature range, the isothermal dehydrogenation study are normally used to judge material performance characteristics such as storage capacity and kinetics at desired temperature. The Fig. 6 shows the isothermal dehydrogenation performance of the sample $2\left(\mathrm{LiBH}_{4}+0.3 \mathrm{MgCl}_{2}+0.2 \mathrm{TiO}_{2}\right)$. At $673 \mathrm{~K}$, the material desorbed $2.5 \mathrm{wt} \%$ of hydrogen rapidly in the first $15 \mathrm{~min}$. Following two incubation periods, the material desorbed $4.9 \mathrm{wt} \%$ of hydrogen in 18 hours. The second desorption at $773 \mathrm{~K}$ is almost same with $4.9 \mathrm{wt} \%$ of hydrogen released in 18 hours. In the third dehydriding, the materials desorbed $4.25 \mathrm{wt} \%$ hydrogen in 22 hours. It is interested that there is no incubation in the third dehydriding. It may imply the settle down of certain material interaction. The repeatedly dehydriding and rehydriding shows the reversibility of the material, at least in the preliminary expression. Obviously, the desorption kinetics is too slow for practical application. But, there are number of the ways to improve the kinetics such as reduce the particle size to nanoscale, disperse the materials on the nonporous subtract, synthesize thin film and add catalysts to change the reaction path and so on. We believe that the reducing thermodynamic stability while maintain high capacity is the focused points of the development of reversible borohydride materials. 


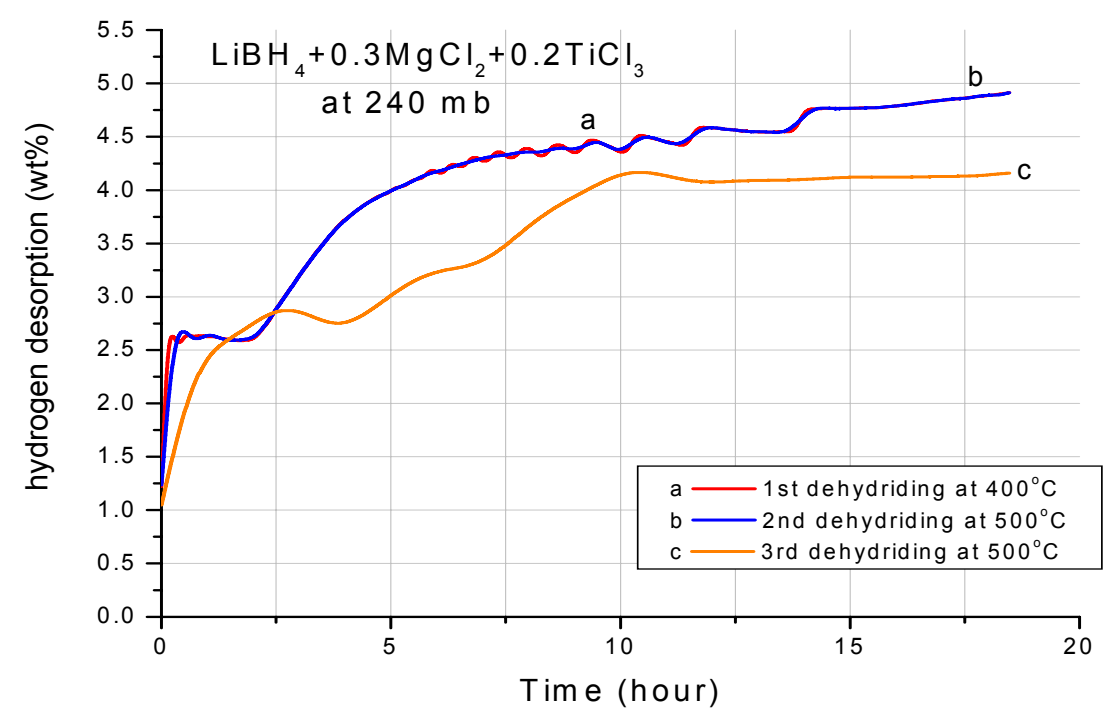

Fig. 6 The isothermal hydrogen desorption of the material $\mathrm{LiBH}_{4}+0.3 \mathrm{MgCl}_{2}+0.2 \mathrm{TiCl}_{3}$

\section{$\underline{4.3}$ Isothermal rehydriding of the selected borohydrides}

After dehydriding at $873 \mathrm{~K}$ for one hour, the sample $3\left(\mathrm{LiBH}_{4}+0.3 \mathrm{MgCl}_{2}+0.3 \mathrm{TiO}_{2}\right)$ was selected for rehydrogenation at $873 \mathrm{~K}$ and 70 bars. As Fig. 7 shows, the material absorbs $2.8 \mathrm{wt} \%$ of hydrogen in 17 hours, but it absorbed more hydrogen $(4.4 \mathrm{wt} \%)$ in the second rehydrogenation. It is not clear that if more dehydriding-rehydriding cycling will result to higher capacity or fast kinetics. But, it demonstrates that the material is the reversible in the limited cycles. In other side, the rehydrogenation kinetics of the destabilized $\mathrm{LiBH}_{4}$ is much slower comparing with catalyzed $\mathrm{LiBH}_{4}$ reported in the previous paper 1]. Also, the rehydriding temperature and pressure are still too high for immediately application. More work has to be done.

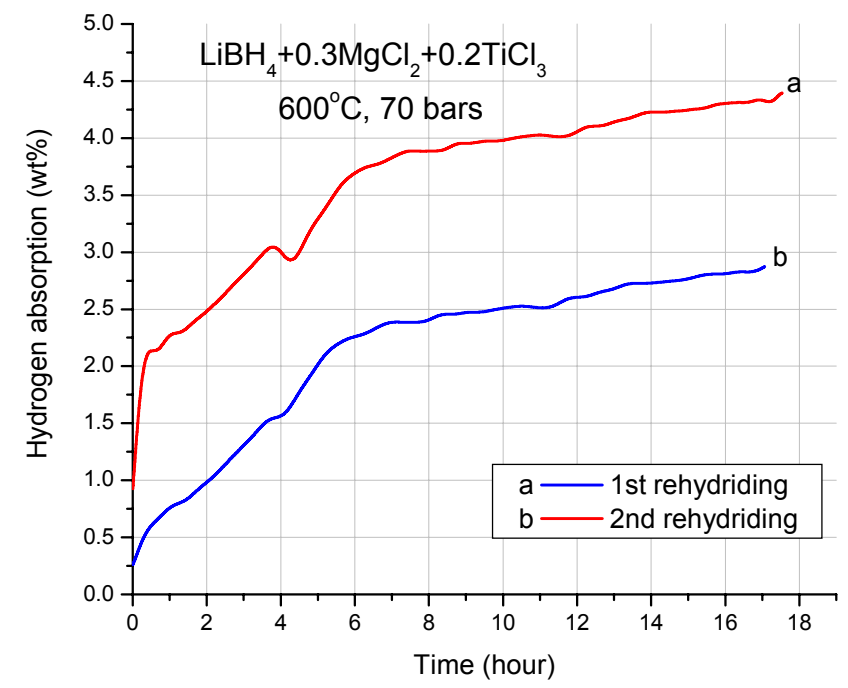


Fig. 7 Hydrogen absorption of the material $\mathrm{LiBH}_{4}+0.3 \mathrm{MgCl}_{2}+0.2 \mathrm{TiCl}_{3}$

\section{$\underline{4.4 \text { Raman scattering analysis of the destabilized } \mathrm{LiBH}_{4}}$}

At room temperature, two Raman active internal $\mathrm{BH}_{4}{ }^{-1}$ vibrations $v_{4}$ and $v_{4}{ }_{4}$ occur at 1253 and $1287 \mathrm{~cm}^{-1}$ respectively, and two overtones $2 v_{4}$ and $2 v_{4}{ }^{\prime}$ at 2240 and $2274 \mathrm{~cm}^{-1}$, respectively as blue spectrum shows in the Fig.8. However, the $v_{4}, v^{\prime}{ }_{4}$, and $2 v_{4}$ stretching disappear from the spectrum after adding agents in the material $\mathrm{LiBH}_{4}+0.5 \mathrm{LiAlH}_{4}$. The $2 v_{4}$ ' stretching is weakened and shifted to $2300 \mathrm{~cm}^{-1}$ as the red spectrum shows in the Fig.8. It is implied that the $\mathrm{B}-\mathrm{H}$ binding strength is changed by partial $\mathrm{Li}^{+1}$ substitution. The weakened bond results in lower dehydriding temperature. Similar result was obtained from material $\mathrm{LiBH}_{4}+0.3 \mathrm{MgCl}_{2}+0.2 \mathrm{TiCl}_{3}$, see Fig.9.

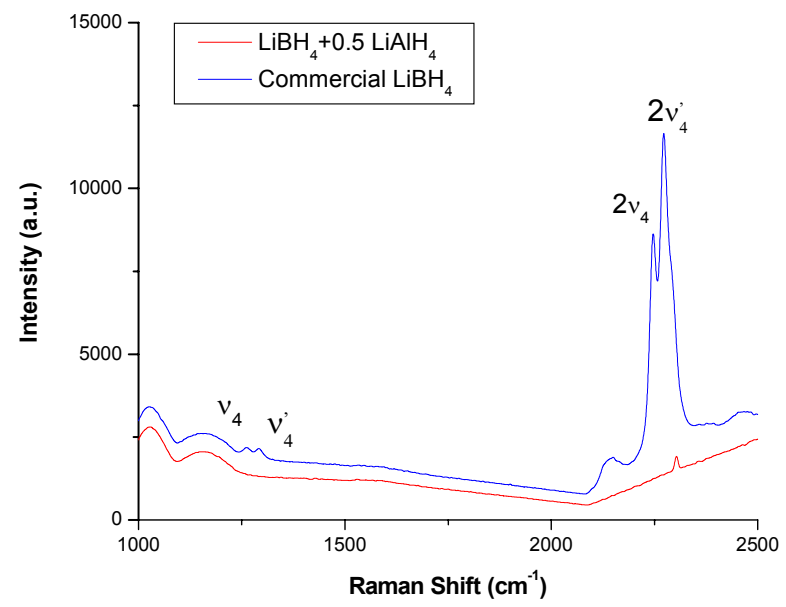

Fig. 8 Raman spectra of $\mathrm{LiBH}_{4}+0.5 \mathrm{LiAlH}_{4}$

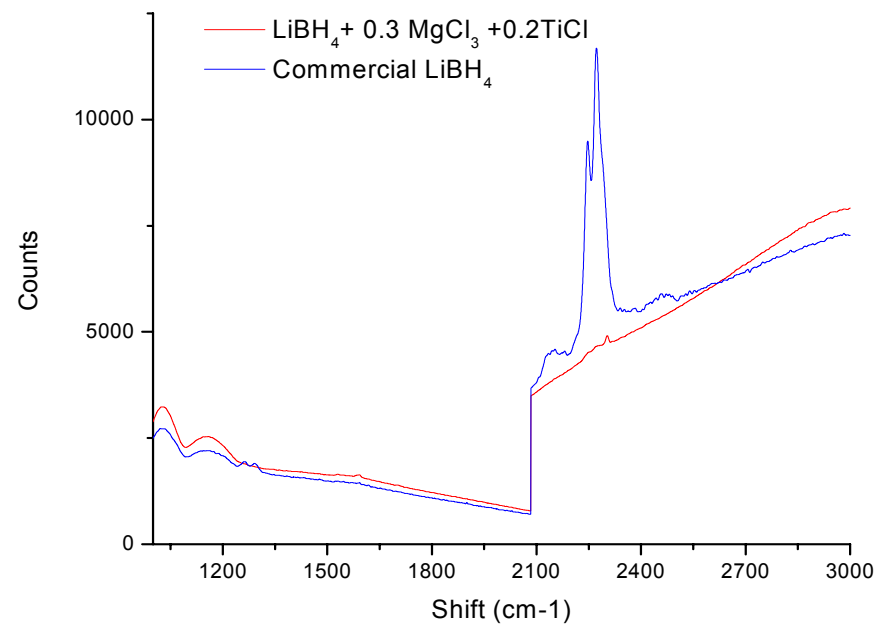

Fig.9 Raman spectra of $\mathrm{LiBH}_{4}+0.3 \mathrm{MgCl}_{3}+0.2 \mathrm{TiCl}_{3}$ 


\section{Conclusions}

In attempt of destabilizing lithium borohydride, a number of metals, metal hydrides, metal chlorides and metal complex hydrides have been selected and evaluated as the destabilization agents. The experimental results show that additives, such as $\mathrm{Mg}, \mathrm{Al}$, $\mathrm{MgH} 2, \mathrm{AlH} 3, \mathrm{CaH} 2, \mathrm{MgCl} 3, \mathrm{TiCl} 3$ and $\mathrm{LiAlH} 4$, are effective in reducing dehydriding temperature, but some are negative such as $\mathrm{Ni}, \mathrm{C}, \mathrm{In}, \mathrm{Ca}$ and $\mathrm{NaH}$. The destabilized lithium borohydrides are reversible in the limited dehydriding-rehydriding cycles with slow reaction kinetics. The required rehydriding temperature and pressure are still elevated. Raman spectroscopic analysis shows $\mathrm{H}-\mathrm{B}$ stretch change after adding of destabilization agents. The material $\mathrm{LiBH}_{4}+0.3 \mathrm{MgCl}_{3}+0.2 \mathrm{TiCl}_{3}$ desorbed $5 \mathrm{wt} \%$ of hydrogen from $333 \mathrm{~K}$ and desorbed $4.5 \mathrm{wt} \%$ of hydrogen at $873 \mathrm{~K}$ and $7 \mathrm{MPa}$ during rapidly dehydriding-rehydriding cycles. This investigation indicates that the thermodynamic stability of lithium borohydride can be reduced by the additives. More comprehensive work could lead to possible breakthrough in developing new lithium borohydride based materials for reversible hydrogen storage with practical operating conditions.

\section{Acknowledgement}

The author thanks Drs. J. Holder and T. Motyka, Dr. K. Heung and K. Shanahan for discussion, comments and encouragement. The author also thanks Drs. A. Jurgensen and K. Zeigler for Raman spectroscope analysis. This project is financially supported by NNSA/PDRD program. Savannah River National Laboratory is operated by Washington Savannah River Company for US Department of Energy under contract DE-AC0996SR18500.

\section{References:}

[1] M.Au and A. Jurgensen, J.Phy.Chem. B. V110 (2006) 7062-7067

[2] A.Zuttel, S.Rentsch, Ch.Emmenegger et al, J.Alloy.Comp. 356-357(2003)515-520

[3] Y. Nakamori and S.Orimo, J.Alloy.Comp. 370(2004)271-275

[4] M.Au, US Patent Application, 60/605177, published on 3/1/2006

[5] J.Vajo and S.Skeith, J.Phys.Chem.B. V109, N9(2005) 3719-3722 